\title{
Circadian rhythm of melatonin secretion and growth-related gene expression in the tiger puffer Takifugu rubripes
}

\author{
Byeong-Hoon $\mathrm{Kim}^{1+}{ }^{\dagger}$, Sung-Pyo Hur ${ }^{5}$, Sang-Woo Hur ${ }^{2}$, Yuki Takeuchi ${ }^{3}$, Akihiro Takemura ${ }^{4}$ and Young-Don Lee ${ }^{1,6^{*}}$
}

\begin{abstract}
Somatostatin (SS) and growth hormone-releasing hormone (GHRH) are primary factors regulating growth hormone $(\mathrm{GH})$ secretion in the pituitary. To date, it remains unknown how this rhythm is controlled endogenously, although there must be coordination of circadian manners. Melatonin was the main regulator in biological rhythms, and its secretion has fluctuation by photic information. But relationship between melatonin and growth-related genes (ghrh and ss) is unclear. We investigated circadian rhythms of melatonin secretion, ghrh and ss expressions, and correlation between melatonin with growth-related genes in tiger puffer Takifugu rubripes. The melatonin secretion showed nocturnal rhythms under light and dark (LD) conditions. In constant light (LL) condition, melatonin secretion has similar patterns with LD conditions. SS1 mRNA was high during scotophase under LD conditions. But ss 1 rhythms disappeared in LL conditions. Ghrh appeared opposite expression compared with melatonin levels or ss 1 expression under LD and LL. In the results of the melatonin injection, ghrh and ss 1 showed no significant expression compared with control groups. These results suggested that melatonin and growthrelated genes have daily or circadian rhythms in the tiger puffer. Further, we need to know mechanisms of each ss and ghrh gene regulation.
\end{abstract}

Keywords: Photoperiod, Melatonin, Somatostatin, GHRH, Tiger puffer

\section{Background}

Biological rhythms are controlled by many environmental changes including light, temperature, universal gravitation, and weather conditions (Fraser et al. 1993; Forward et al. 1998; Wan et al. 2013; Guerra-Santos et al. 2017). In non-mammalian vertebrates, photic signals are transmitted via neural pathways from the retina to the pineal gland. These signals control the secretion of various hormones (Iigo et al. 1997; Ayson and Takemura 2006; Revel et al. 2006; Moore and Menaker 2011; Hur et al. 2011).

Body growth is enhanced by growth hormone (GH), which is released from the pituitary gland in vertebrates (McLean et al. 1997; Raven et al. 2012; Fuentes et al. 2013). The secretion of GH is primarily controlled by growth hormone-releasing hormone (GHRH) and

\footnotetext{
* Correspondence: leemri@jejunu.ac.kr

'Equal contributors

${ }^{1}$ Marine Science Institute, Jeju National University, Jeju 6333, South Korea

619-5, Hamdeok 5(0)-gill, Jocheon, Jeju Special Self-Governing Province

695-965, Republic of South Korea

Full list of author information is available at the end of the article
}

somatostatin (SS), which are synthesized in the hypothalamus (Klein and Sheridan 2008; Luque et al. 2008). Moreover, IGF-1, which is secreted from the liver, is also known to control body growth through interactivity with GH (Wood et al. 2005). Studies show that GH secretion is controlled by various environmental factors such as temperature and photoperiod.

GHRH is a member of the glucagon superfamily, and its primary function is to stimulate $\mathrm{GH}$ synthesis and secretion by binding to GHRH receptors (GHRHR) in the anterior pituitary. Recent studies in fish show that GHRH and pituitary adenylate cyclase-activating peptide (PACAP) encodings differ by only a single gene, and GH induction in the pituitary gland by GHRH has been identified (Lee et al. 2007). In contrast, SS has been widely detected not only in the central nervous system but also in peripheral tissues. It inhibits GH secretion in the pituitary (Very et al. 2001). These two GHregulating hormones, GHRH and SS, have opposing functions: GHRH enhances GH release from the pituitary in vivo and in vitro, while SS inhibits its secretion in many teleost fishes (Canosa et al. 2007). 
Melatonin is an indole-derived hormone that is synthesized in the retina and pineal gland. The secretion of this hormone is primarily controlled by environmental light conditions in vertebrates, including fish. The plasma melatonin level in Mozambique tilapia Oreochromis mossambicus increases during the night and decreases at day (Nikaido et al. 2009). Although it has been suggested that melatonin secretions affect physiological functions, including body growth in fish (Taylor et al. 2005; Herrero et al. 2007; De Pedro et al. 2008; Maitra et al. 2013), the effect of melatonin on the transcription of growth-related genes (ghrh and ss) is still unclear.

The tiger puffer Takifugu rubripes is a commercially valuable species in South Korea. The aim of the present study is to profile its growth-related gene expressions and to evaluate the effect of melatonin on expressions of these genes.

\section{Methods}

\section{Animal}

A total of 200 tiger puffer T. rubripes (body weight $128.4 \pm 2.1 \mathrm{~g}$, body length $18.7 \pm 0.1 \mathrm{~cm}$ ) were used in this study. Fish were obtained from the Tham-Ra Fishery located in Soegwipo, Jeju, South Korea, and transported to Marine Research Institute, Jeju National University. The fish were acclimatized under natural photoperiod and water temperature $\left(20-21{ }^{\circ} \mathrm{C}\right)$. The fish were fed commercial pellets (Daehan co., MP3, Busan, South Korea) equivalent to 1 to $2 \%$ of body weight at 0900 and 1600 h daily.

Distribution of growth-related genes in the parts of brain were examined by RT-PCR and real-time quantitative RT-PCR (Real-time PCR). The fish $(n=4)$ brain were divided to five portions each, the telencephalon, optic tectum, diencephalon, cerebellum, and medulla oblongata (Hur et al. 2011) (Fig. 1). Sampling was conducted at $1200 \mathrm{~h}$ during the daytime, and sampling methods was explained above.

For the circadian variation, fish were adapted under 12-h light and 12-h dark photoperiod condition (12L:12D, light on $=0800 \mathrm{~h}$ and light off $=2000 \mathrm{~h}$ ) for 1 week. After adapted, fish were divided into two groups; 12L:12D group and 24-h light photoperiod condition (24L) group. The 12L:12D group fish $(n=98, \mathrm{BW}$ $126.2 \pm 4.1 \mathrm{~g}$, TL $18.0 \pm 0.2 \mathrm{~cm}$ ) and $24 \mathrm{~L}$ group fish $(n=98$, BW $136.4 \pm 3.1 \mathrm{~g}$, TL $19.0 \pm 0.2 \mathrm{~cm})$ were reared for 3 days. Fish were anesthetized in MS-222 and killed by decapitation at 4-h intervals for 1 day at zeitgeber time (ZT) 2, ZT 6, ZT 10, ZT 14, ZT18, and ZT 22 for 12L:12D group and circadian time (CT) 2, CT 6, CT 10, CT 14, CT 18, and CT 22 for 24L group fish. The two experimental groups were sampled at the same time in different light conditions. The sampling at darkness time was conducted under red dim light, and blood plasma, diencephalon, and pituitary were collected as described above. The collected blood plasma were used in melatonin levels' analysis, and diencephalon tissues were used in $g h r h 1, g h r h 2$, and ss mRNA expression analysis by fluoroimmuno assay (TR-FIA) and real-time qPCR. The experimental procedures followed the guidance approved by the Animal Care and Use committees of Jeju National University, Jeju, South Korea.

\section{Melatonin intraperitoneal injection}

A total of 20 fish were used for the effects of melatonin with several growth-related genes. Fish were reared under natural photoperiod and water temperature. The one group of fish was melatonin (Sigma, $1 \mathrm{mg} / \mathrm{kg}$, $n=10$ ) treated by intraperitoneal injection (i.p.), and the other group was injected with the only vehicle solution $(0.6 \%$ of saline, $n=10)$ at $1100 \mathrm{~h}$. The fish of melatonin
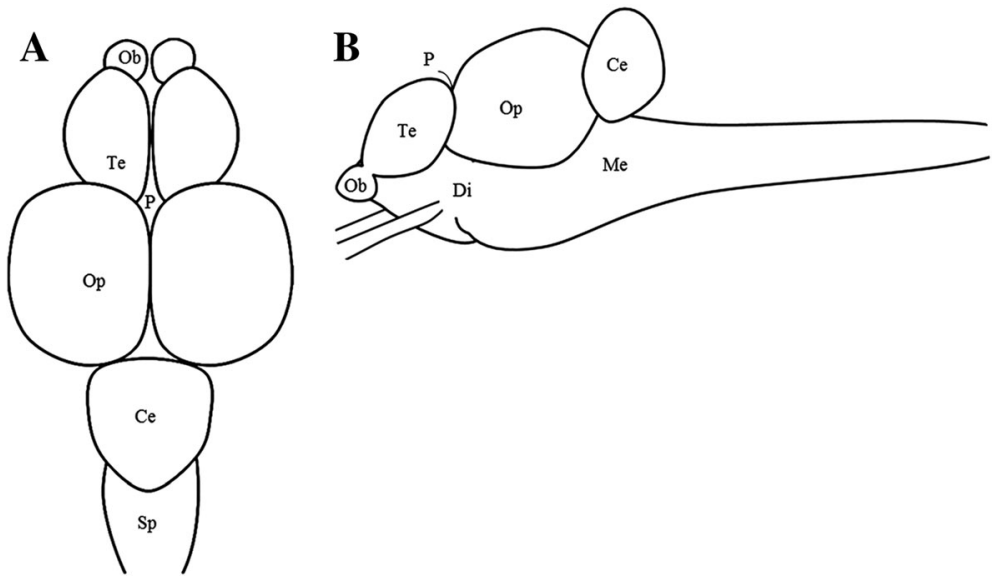

Fig. 1 Diagram showing dorsal view (a) and sagittal plane (b) of the puffer fish brain. Ob olfactory bulb, Te telencephalon, Op optic tectum, Ce cerebellum, $P$ pineal gland, $P O N$ preoptic nucleus, Sp spinal cord 
i.p. and vehicle groups were sampled melatonin i.p. after $1 \mathrm{~h}$. Fish were anesthetized with MS-222 before sampling, and tissues were collected (diencephalon and pituitary) by decapitation. The collected samples were kept at $-80{ }^{\circ} \mathrm{C}$ until the analysis.

\section{Plasma melatonin measurement}

The levels of melatonin were measured by time-resolved fluoroimmuno assay (TR-FIA) according to the previous report (Takemura et al. 2004). Briefly, a 96-well plate (AGC Techno Glass) was coated with $50 \mathrm{mM}$ carbonate buffer, pH 9.6 (100 ll/well), containing a melatonin-bovine serum albumin (BSA) conjugate $(5 \mathrm{ng} / \mathrm{ml})$ for $2 \mathrm{~h}$ at $24 \pm 0.5{ }^{\circ} \mathrm{C}$ in an incubator (Sanyo). After three washes with DELFIA wash buffer, $50 \mathrm{ll}$ of samples/standards $(7.8-4000 \mathrm{pg} / \mathrm{ml})$ and $50 \mathrm{ll}$ of anti-melatonin (1:200,000 in assay buffer) were placed in the wells. The plate was incubated overnight at $4{ }^{\circ} \mathrm{C}$. After washing, $100 \mathrm{ll}$ of the secondary antibody against rabbit immunoglobulin $\mathrm{G}$ labeled with europium (1:1000 in assay buffer) was added to the well and incubated at $24{ }^{\circ} \mathrm{C}$ for $1 \mathrm{~h}$. After washing, $50 \mathrm{ll}$ of DELFIA enhancement solution was added to the wells. The signal in each well was quantified using a time-resolved fluorometer (Arcus1234, Wallac, Oy, Finland). The composition of the assay buffer $(\mathrm{pH} 7.75)$ used in the present study was $0.05 \mathrm{M}$ Tris, $0.9 \% \mathrm{NaCl}$, 0.5\% BSA, (Sigma), 0.05\% NaN3, $0.01 \%$ Tween 40 , and $20 \mathrm{lM}$ diethylenetriaminepentaacetic acid (DTPA, Kanto Chemicals, Tokyo, Japan). DELFIA washing buffer ( $\mathrm{pH}$ 7.75) contained $0.05 \mathrm{M}$ Tris, $0.9 \%$ $\mathrm{NaCl}, 0.1 \% \mathrm{NaN} 3$, and $0.01 \%$ Tween 20.

\section{RT-PCR and real-time quantitative PCR}

Total RNA was extracted from the tissues of tiger puffer using the RNAiso Reagent (TaKaRa Bio, Japan) after absolutely homogenizing the samples. And $1 \mu \mathrm{g}$ of total RNA was used for synthesis of first strand cDNA by Transcriptor First strand cDNA synthesis kit (Roche Diagnostics, Mannheim, Germany). Primer sets of each genes were designed by isolated ghrh1 (Gene bank, accession number; DQ659331), ghrh2 (DQ659332), ss1 (XM_003968318), and $\beta$-actin (U37499) of tiger puffer from National Center for Biotechnology Information (NCBI, Table 1). For the RT-PCR, each PCR reaction mix contained 50\% of Emerald PCR Master mix (TaKaRa-Bio), $10 \mu \mathrm{m}$ of each forward and reverse primer, and $50 \mathrm{ng}$ of cDNA template. The RTPCR cycling conditions were followed by 28 cycles of denaturation for $45 \mathrm{~s}$ at $94{ }^{\circ} \mathrm{C}$, annealing for $45 \mathrm{~s}$ at $58{ }^{\circ} \mathrm{C}$, and extension for $1 \mathrm{~min}$ at $72{ }^{\circ} \mathrm{C}$. The real-time quantitative PCR was performed using the CFX ${ }^{\mathrm{Tn}}$ Real-time System (Bio-Rad, Hercules, CA, USA) with 20 ng of cDNA using FastStart Universal SYBR Green Master (Roche Diagnostics). The real-time quantitative PCR amplification was performed by initial denaturation at $95^{\circ} \mathrm{C}$ for $10 \mathrm{~min}, 40 \mathrm{cy}$ cles of $95{ }^{\circ} \mathrm{C}$ for $15 \mathrm{~s}, 60{ }^{\circ} \mathrm{C}$ for $1 \mathrm{~min}$, and last $60{ }^{\circ} \mathrm{C}$ for
Table 1 Primer sets used in this study

\begin{tabular}{lll}
\hline Primers & Sequence (5'-3') & $\begin{array}{l}\text { GeneBank } \\
\text { Accession No. }\end{array}$ \\
\hline $\begin{array}{l}\text { ss1- F } \\
\text { ssl-R }\end{array}$ & TCTGCTACT GCAGT CCAACG CCTT & XM_003968318 \\
ghrh 1- & TACAGCGT CAT CT GCT CACC & DQ659331 \\
ghrh 1- & GAAGGAGT AGAGGT CGT CAGC & \\
$R$ & & \\
ghrhl-V & AGCGT CTT CT GCACACCT AT C & DQ659332 \\
ghrh 1- & AGT ACGCAT CGTCGTCTACC & \\
$R$ & & \\
yS- & GCCAT CCTT CCTT GGT AT GGA & \\
actin-F & & \\
yS- & GT CGTACT CCT GCTT GCT GA & \\
actin- $R$ & \\
\hline
\end{tabular}

$1 \mathrm{~min}$. Growth-related gene expressions in diencephalon were normalized to amount of the internal control $\beta$-actin gene.

\section{Statistical analysis}

The plasma melatonin levels and growth-related genes were expressed as means \pm SEM and considered significantly different at $P<0.05$. Data were analyzed by oneway analysis of variance (ANOVA) followed by Tukey's test to assess statistically significant differences among the different time points in the daily and circadian variation experiments. The significant differences of growth-related gene expression after melatonin injection were tested by Student's $t$ test. $P<0.05$ was considered significant.

\section{Results}

The mRNA expression of growth-related genes in central nerves tissues

We profiled the distribution of the growth-related gene expression in the several parts of the tiger puffer brain by RT-PCR (Fig. 2a) and real-time qPCR (Fig. 2b-d). The ss 1 expression was detected in the telencephalon $(\mathrm{Te})$, optic tectum $(\mathrm{Op})$, diencephalon $(\mathrm{Di})$, and medulla oblongata (ME) but not in the cerebellum (Ce), while the ghrh1 and ghrh2 seemed to express in the all parts of the brain (Fig. 2a).

The $s s 1$ was significantly highly expressed in the $\mathrm{Te}, \mathrm{Di}$, and ME than Op and Ce (Fig. 2b). The significantly highest expression of ghrh1 was observed in the ME, and the highest expression of ghrh2 was detected in the Te (Fig. 2c, d).

\section{Daily and circadian rhythm of melatonin and growth- related genes}

Plasma melatonin levels were significantly elevated at the middle of the night (ZT18), and its higher level was kept until the dark phase under 12L:12D conditions (Fig. 3a). When the fish were reared under $24 \mathrm{~L}$ conditions, the plasma melatonin showed similar patterns with that under 

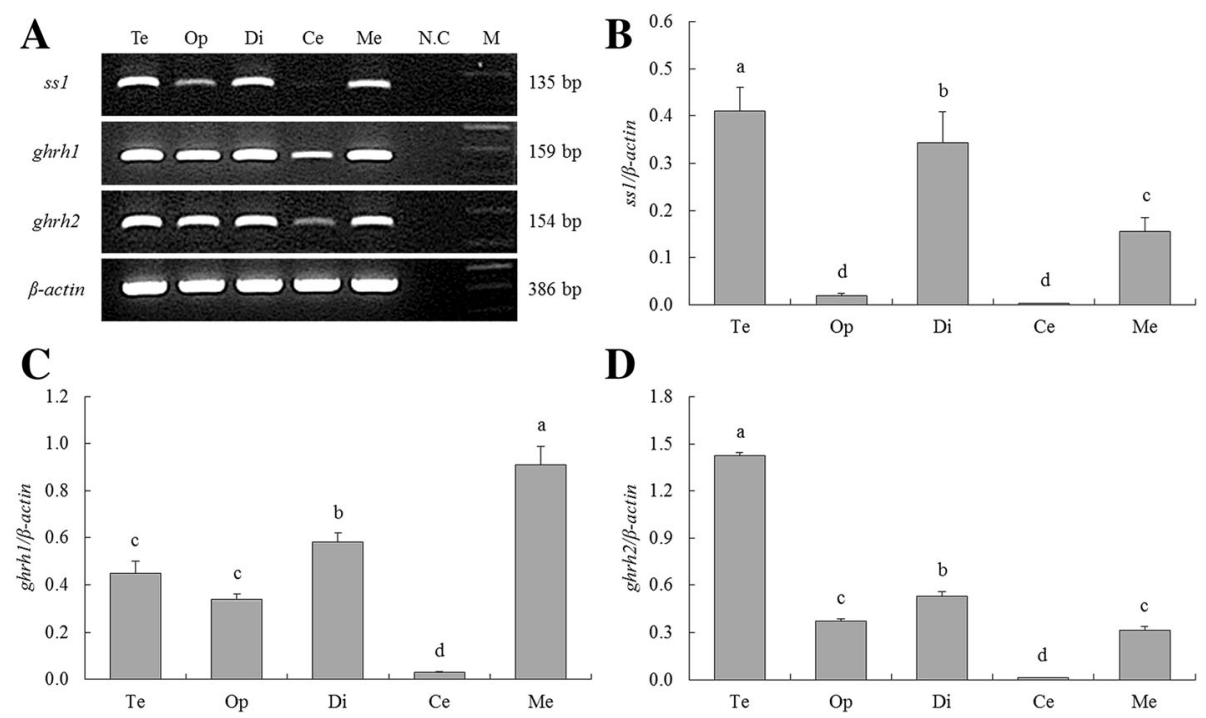

Fig. 2 Tissue-specific expression of growth-related genes in the portion of the brain of tiger puffer. The brain was further divided into five parts. They were analyzed by RT-PCR (a) and qPCR (b-d). The expression of $\beta$-actin mRNA was used as reference. Te telencephalon, Op optic tectum, Di diencephalon, Ce cerebellum, Me medulla oblongata, N.C negative control, M 100 bp DNA ladder marker. Means represented by different letters are significant $(P<0.05)$. Values are mean \pm SEM

12L:12D conditions (Fig. 3b). Under 12L:12D conditions, ss1 expression in the diencephalon was more increased during scotophase than photophase (Fig. 4a). ss1 mRNA showed the highest expression at ZT18, and the lowest expression was detected at ZT2. However, this significant $(P<0.05)$ expression patterns disappear under 24L conditions (Fig. 4b).

Each ghrh1 and ghrh2 mRNA in the diencephalon showed alike expression patterns under 12L:12D and 24L conditions. Expression of ghrh1 mRNA was more increased during photophase than scotophase under 12L:12D conditions, but its rapidly low expression was detected in ZT6 (Fig. 5a). Under 24L conditions, ghrh1 mRNA showed different expression patterns compared with 12L:12D conditions, and this mRNA detected no sudden low expression in CT6 (Fig. 5b). ghrh2 mRNA showed alike expression pattern with ghrh1 mRNA under all experiment conditions (Fig. 6a, b). This gene revealed significant expressions under $12 \mathrm{~L}: 12 \mathrm{D}$ and $24 \mathrm{~L}$ conditions. But, this gene detected no significant expression between photophase and scotophase.

\section{Effect of melatonin treatment on the expressions of growth-related genes}

The expression of growth-related genes in the diencephalon and pituitary after melatonin i.p. were analyzed by qPCR. One hour after melatonin i.p., ss1 mRNA showed higher expression levels in melatonin group than saline group (Fig. 7a). However, ghrh1 and ghrh2 mRNA after melatonin i.p. showed no different expression in the melatonin group with saline group (Fig. 7b, c).

\section{Discussion and conclusions}

Photoperiod is a well-known regulation factor for many physiological responses in fish, including growth and development (Norberg et al. 2001; Taylor et al. 2005; Biswas et al. 2008; Gunnarsson et al. 2012). In this study, we decided to evaluate the effect of light/dark cycle on the expression of growth-related genes in the tiger puffer.

The distribution of growth-related genes in the brain tissue was evaluated using RT-PCR and qPCR. The data revealed widespread distribution of these genes in the brain (Fig. 2), similar to that in the orange-spotted grouper Epinephelus coioides (Xing et al. 2005; Qian et al. 2012). In the orange-spotted grouper, the expression of ss mRNA was detected in all brain regions, excluding the epithalamus. Ghrh mRNA was also expressed in many brain regions. These data suggest that ss and ghrh expression may mediate not only GH secretion in the pituitary but also multiple biological functions in the tiger puffer.

The daily and circadian regulation of melatonin is well known in vertebrates, including fish. Plasma melatonin levels in the Senegalese sole Solea senegalensis showed typical daily rhythms consisting of low levels during photophase and high levels during scotophase (Bayarri et al. 2004). For tench Tinca tinca identified the circadian secretion of melatonin under continuous dark conditions as well as light and dark conditions (Oliveira et al. 2009). Our experimental data showed similar results; plasma melatonin secretion in tiger puffers increased during the dark phase in 12L:12D conditions (Fig. 3a). Similar melatonin secretion patterns were found during 


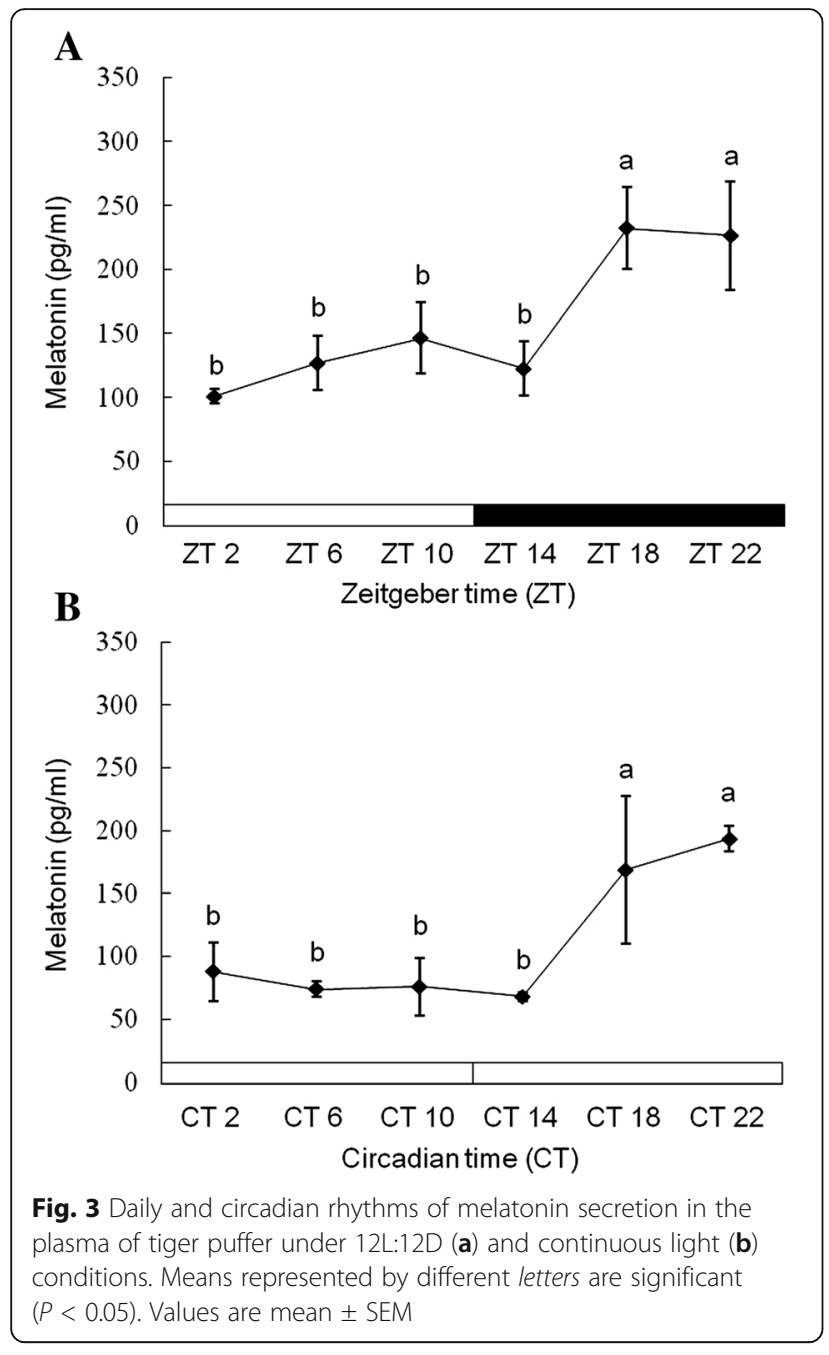

continuous light conditions (Fig. 3b). In some fishes, the rise of melatonin secretion during scotophase is controlled using an endogenous clock. In pike Esox and zebrafish Danio rerio, the expression of the melatonin synthesis gene (arylalkylamine $N$-acetyltransferase (AANAT)) shows nocturnal rhythms in 12L:12D conditions, and this gene has similar expression rhythms during continuous light or dark conditions (Bégay et al. 1998). These fish have circadian rhythms of high secretion during scotophase caused by the circadian oscillation of the AANAT gene via an endogenous clock. Therefore, we suggest that melatonin have the circadian rhythm in the tiger puffer.

SS and GHRH regulate the synthesis and secretion of $\mathrm{GH}$ in the pituitary of vertebrates, including fish (Bertherat et al. 1995; Sheridan and Hagemeister 2010). However, SS and GHRH rhythms in fish are not well understood since the majority of research has focused on mammals. Circadian variation of SS levels in rat plasma showed more elevation during scotophase than

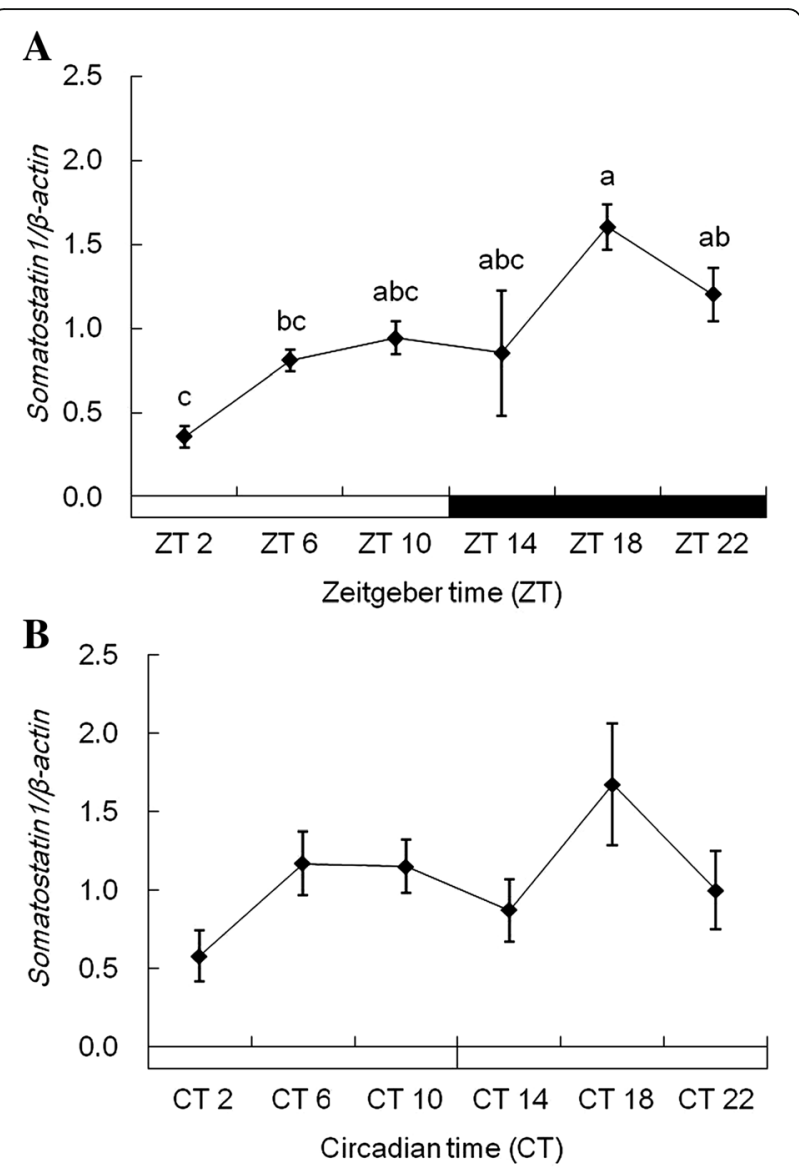

Fig. 4 Daily and circadian expressions of ss 1 mRNA in the diencephalon of tiger puffer under 12L:12D (a) and continuous light (b) conditions. The relative values of somatostatin $1 \mathrm{mRNA}$ expressions were normalized against $\beta$-actin and then averaged. Means represented by different letters are significant $(P<0.05)$. values are mean \pm SEM

during photophase (Peinado et al. 1990; Ishikawa et al. 1997). We investigated biological rhythms of growthrelated genes in the diencephalon of the tiger puffer. The expression patterns of ss $1 \mathrm{mRNA}$ were similar to those shown in previous studies. The $s s 1$ mRNA expression in the diencephalon of tiger puffers increased during the dark phase in 12L:12D conditions (Fig. 4). However, ss1 mRNA expression rhythm disappeared under $24 \mathrm{~L}$ conditions. Therefore, ss $1 \mathrm{mRNA}$ suggest to have the daily rhythm according to light and dark.

In our presents, $g h r h 1$ and $g h r h 2$ mRNA exhibited diurnal rhythms in tiger puffers (Figs. 5 and 6). In rats, ghrh mRNA expression also exhibited diurnal rhythms (Bredow et al. 1996). Peak expression of hypothalamic ghrh mRNA occurred during the early part of photophase in rats. The ghrh expression gradually decreased up to scotophase, and the mRNA expressions maintained low levels during scotophase. Diurnal rhythms of hypothalamic ghrh mRNA were also observed in rats (Gardi et al. 1999). In these 


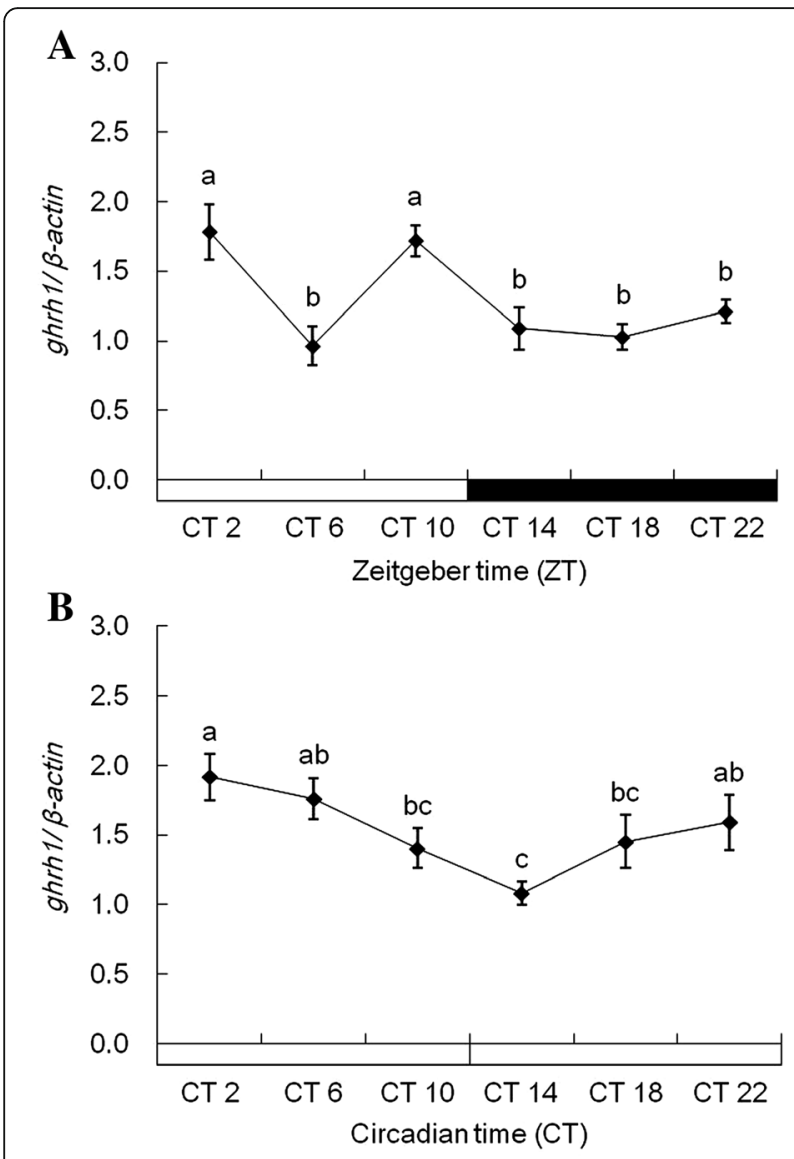

Fig. 5 Daily and circadian expressions of ghrh 1 mRNA in the diencephalon of tiger puffer under 12L:12D (a) and continuous light (b) conditions. The relative values of ghrh1 mRNA expressions were normalized against $\beta$-actin and then averaged. Means represented by different letters are significant $(P<0.05)$. Values are mean \pm SEM

studies, hypothalamic ghrh levels increased rapidly in the first hour after light onset, then decreased for $4 \mathrm{~h}$ after light onset. The ghrh level gradually increased up to the beginning of scotophase and then steadily decreased during scotophase. The ghrh1 and ghrh2 mRNA rhythms in tiger puffers in this study were similar to the ghrh mRNA rhythms in rats. The expression of ghrh1 mRNA in tiger puffers was high in the early part of photophase and then decreased toward the midpoint of photophase. Further, the ghrh1 mRNA increased from the midpoint up to the end of photophase. During scotophase, ghrh1 mRNA showed prolonged low expression levels. Therefore, we suggest that tiger puffers have daily rhythms of ghrh expression that vary with light and dark conditions.

Our results showed that the $s s 1$ mRNA expression pattern was similar to the pattern of melatonin secretion, but ghrh1 and ghrh 2 mRNA expression patterns were opposite to those of melatonin secretion. We then examined the correlation of melatonin secretion and growth-related gene

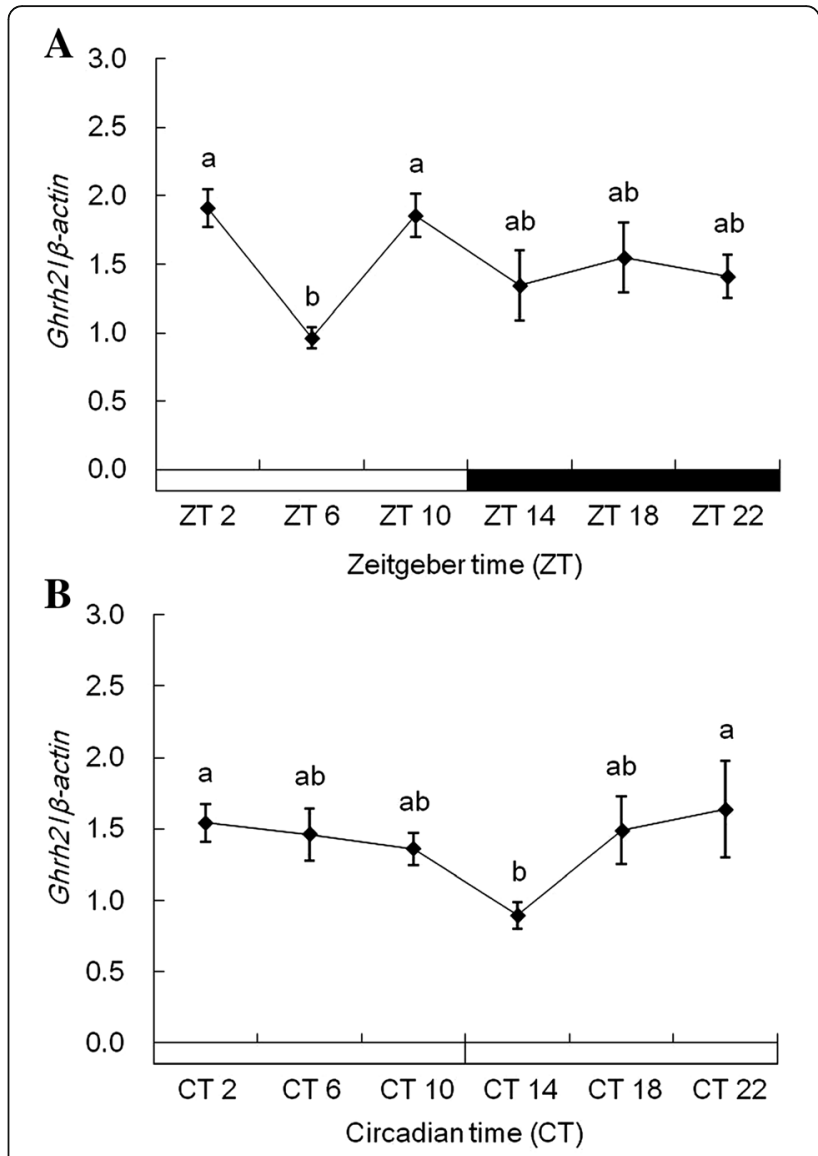

Fig. 6 Daily and circadian expressions of ghrh2 mRNA in the diencephalon of tiger puffer under 12L:12D (a) and continuous light (b) conditions. The relative values of ghrh $2 \mathrm{mRNA}$ expressions were normalized against $\beta$-actin and then averaged. Means represented by different letters are significant $(P<0.05)$. Values are mean \pm SEM

expressions in tiger puffers. In our experiment, ss1 mRNA in diencephalon of tiger puffer was showed inducing expression by melatonin i.p (Fig. 7a). But, no effect of melatonin on mRNA expressions of ghrh1 and ghrh2 was detected (Fig. 7b, c). This suggests that the daily fluctuation of $s s 1$ gene in the tiger puffer is controlled by melatonin, but not ghrh gene. Few studies have addressed the correlation of melatonin with SS or GHRH in vertebrates, including mammals. Our review of the literature found studies only on the relationship of melatonin to SS in the rat hippocampus (Izquierdo-Claros et al. 2004). This study showed a reduction in SS levels through decreasing somatostatinergic system activity, including inhibition of SS receptor activity by melatonin in the hippocampus. Although this finding seems to conflict with our results, we suggest that daily and circadian rhythms of growth-related genes are directly or indirectly controlled by melatonin in the tiger puffer.

Briefly, our results suggest that melatonin secretion and growth-related gene expressions follow daily and circadian rhythms in the tiger puffer. As a result, melatonin showed 


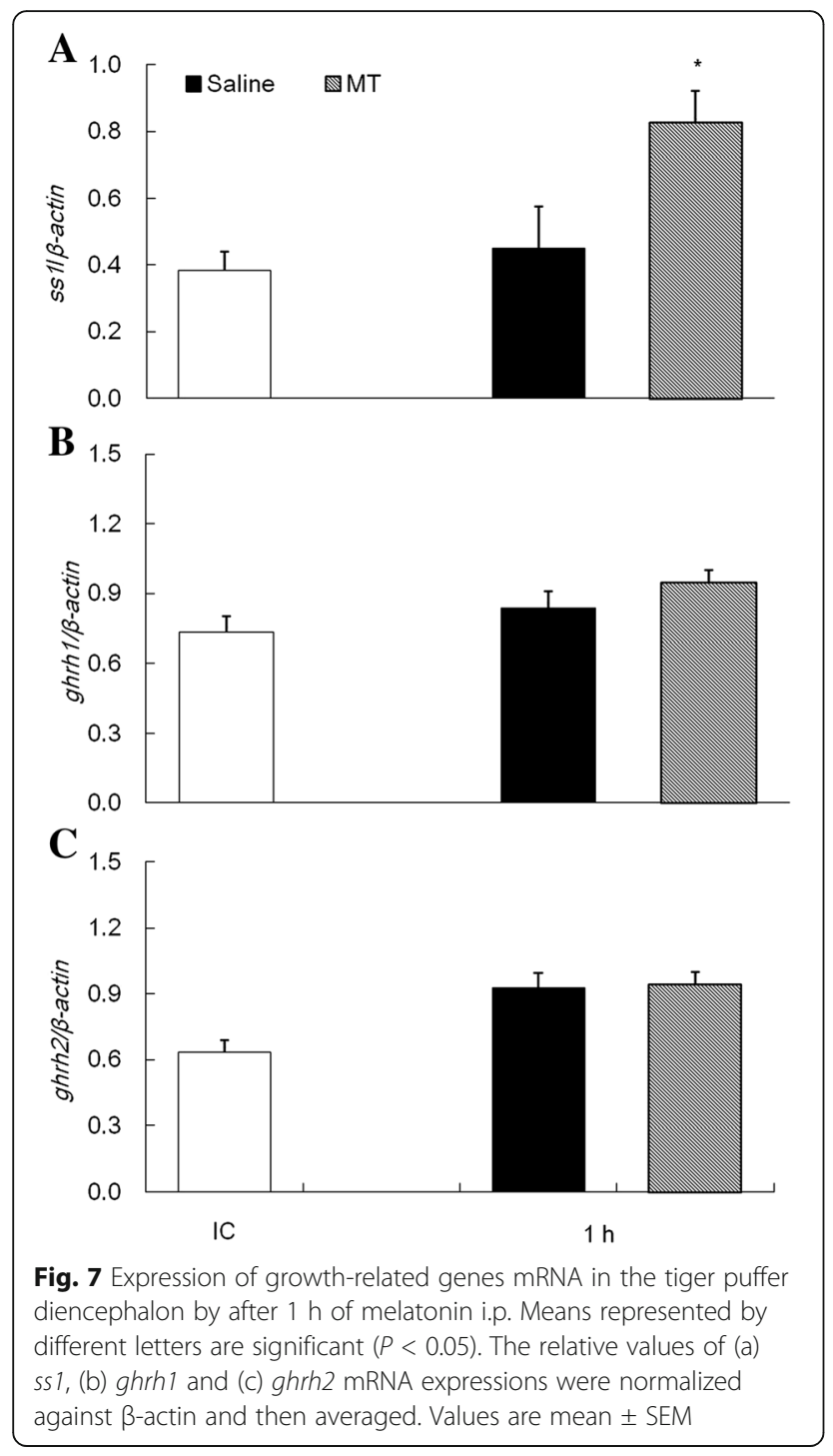

that nocturnal rhythm in $12 \mathrm{~L}: 12 \mathrm{D}$ condition and this rhythm was similarly showed in 24L condition compared with 12L:12D condition. Through these results, melatonin is suggested to have the circadian rhythm regardless of the day and night. The $s s 1$ expression appears to be induction by melatonin treatment. However, ss 1 expression rhythm showed different expression rhythm when compared with melatonin rhythm under $24 \mathrm{~L}$ condition. Therefore, ss 1 mRNA suggest that directly or indirectly regulated by melatonin. The correlation between ghrh expression rhythms with melatonin was not confirmed. Therefore, we more need to further investigate the clarity of the mechanisms between melatonin and growth-related genes.

\section{Abbreviations}

AANAT: Arylalkylamine N-acetyltransferase; GH: Growth hormone; GHRH: Growth hormone-releasing hormone; LD: Light and dark; LL: Constant light; SS: Somatostatin

\section{Acknowledgements}

This research was supported by the Basic Science Research Program through the National Research Foundation of Korea (NRF) funded by the Ministry of Education, Science, and Technology (2012R1A6A3A04041089).

\section{Funding}

This research was supported by the Basic Science Research Program through the National Research Foundation of Korea (NRF).

\section{Availability of data and materials}

Not applicable.

\section{Authors' contributions}

$\mathrm{BH}$ and SP designed and carried out the data analysis and manuscript writing. SW participated in the fish sampling and data analysis. YT and AT participated in the plasma melatonin data analysis. YD participated in its design and coordination and helped to draft the manuscript. All authors read and approved the final manuscript.

\section{Ethics approval}

All experiments were conducted in compliance with both the Animal Care and Use Committee guidelines of the JeJu National University.

\section{Consent for publication}

Not applicable.

\section{Competing interests}

The authors declare that they have no competing interests.

\section{Publisher's Note}

Springer Nature remains neutral with regard to jurisdictional claims in published maps and institutional affiliations.

\section{Author details}

${ }^{1}$ Marine Science Institute, Jeju National University, Jeju 6333, South Korea. ${ }^{2}$ Aquafeed Research Center, National Institute of Fisheries Science (NIFS), Pohang 37517, South Korea. ${ }^{3}$ Department of Electrical Engineering and Bioscience, School of Advanced Science and Engineering, Waseda University, Shinjuku, Tokyo 162-8480, Japan. ${ }^{4}$ Department of Chemistry, Biology and Marine Sciences, Faculty of Science, University of the Ryukyus, Nishihara, Okinawa 903-0213, Japan. ${ }^{5}$ Jeju International Marine Science Research \& Logistics Center, Korea Institute of Ocean Science \& Technology, Jeju 63349, South Korea. ${ }^{6}$ 19-5, Hamdeok 5(o)-gill, Jocheon, Jeju Special Self-Governing Province 695-965, Republic of South Korea.

Received: 12 February 2017 Accepted: 20 July 2017

Published online: 08 August 2017

\section{References}

Ayson FG, Takemura A. Daily expression patterns for mRNAs of GH, PRL, SL, IGF-I and IGF-II in juvenile rabbitfish, Siganus guttatus, during 24-h light and dark cycles. Gen Comp Endocrinol. 2006;149:261-8.

Bayarri MJ, Munoz-Cueto JA, López-Olmeda JF, Vera LM, De Lama MR, Madrid JA, Sanchez-Vazquez FJ. Daily locomotor activity and melatonin rhythms in Senegal sole (Solea senegalensis). Physiol Behav. 2004;81:577-83.

Bégay V, Falcón J, Cahill GM, Klein DC, Coon SL. Transcripts encoding two melatonin synthesis enzymes in the Teleost pineal organ: circadian regulation in pike and Zebrafish, but not in trout 1. Endocrinology. 1998;139:905-12.

Bertherat J, Bluet-Pajot MT, Epelbaum J. Neuroendocrine regulation of growth hormone. Eur J Endocrinol. 1995;132:12-24.

Biswas AK, Seoka M, Ueno K, Yong AS, Biswas BK, Kim YS, Taki K, Kumai H. Growth performance and physiological responses in striped knifejaw, Oplegnathus fasciatus, held under different photoperiods. Aquaculture. 2008;279:42-6.

Bredow S, Taishi P, Obél F Jr, Guha-Thakurta N, Krueger JM. Hypothalamic growth hormone-releasing hormone mRNA varies across the day in rats. Neuroreport. 1996;7:2501-6.

Canosa LF, Chang JP, Peter RE. Neuroendocrine control of growth hormone in fish. Gen Comp Endocrinol. 2007;151:1-26. 
De Pedro N, Martínez-Álvarez RM, Delgado M. Melatonin reduces body weight in goldfish (Carassius auratus): effects on metabolic resources and some feeding regulators. J Pineal Res. 2008;45:32-9.

Forward RB, Tankersley RA, Reinsel KA. Selective tidal stream transport of spot (Leistomus xanthurus Lacepede) and pinfish [Lagodon rhomboides (Linnaeus)] larvae: contribution of circatidal rhythms in activity. J Exp Mar Biol Ecol. 1998;226:19-32

Fraser NH, Metcalfe NB, Thorpe JE. Temperature-dependent switch between diurnal and nocturnal foraging in salmon. Pro Royal Soc Lon B. 1993;252:135-9.

Fuentes EN, Valdés JA, Molina A, Björnsson BT. Regulation of skeletal muscle growth in fish by the growth hormone-insulin-like growth factor system. Gen Comp Endocrinol. 2013;192:136-48.

Gardi J, Obal F, Fang J, Zhang J, Krueger JM. Diurnal variations and sleep deprivation-induced changes in rat hypothalamic GHRH and somatostatin contents. Am J Phys. 1999:277:R1339-44.

Guerra-Santos B, López-Olmeda JF, de Mattos BO, Baião AB, Pereira DSP, Sánchez-Vázquez FJ, Cerqueira RB, Albinati RCBA, Fortes-Silva R. Synchronization to light and mealtime of daily rhythms of locomotor activity, plasma glucose and digestive enzymes in the Nile tilapia (Oreochromis niloticus). Com Biochem Physiol A Mol Integr Physiol. 2017;204:40-7.

Gunnarsson S, Imsland AK, Siikavuopio SI, Árnason J, Gústavsson A, Thorarensen $\mathrm{H}$. Enhanced growth of farmed Arctic charr (Salvelinus alpinus) following a short-day photoperiod. Aquaculture. 2012;350:75-81.

Herrero MJ, Martínez FJ, Míguez JM, Madrid JA. Response of plasma and gastrointestinal melatonin, plasma cortisol and activity rhythms of European sea bass (Dicentrarchus labrax) to dietary supplementation with tryptophan and melatonin. J Comp Physiol B. 2007;177:319-26.

Hur SP, Takeuchi Y, Esaka Y, Nina W, Park YJ, Kang HC, Jeong HB, Lee YD, Kim SJ, Takemura A. Diurnal expression patterns of neurohypophysial hormone genes in the brain of the threespot wrasse Halichoeres trimaculatus. Comp Biochem Physiol A Mol Integr Physiol. 2011;158:490-7.

ligo M, Furukawa K, Hattori A, Ohtani-Kaneko R, Hara M, Suzuki T, Tabata M, Aida K. Ocular melatonin rhythms in the goldfish, Carassius auratus. J Biol Rhythm. 1997;12:182-92

Ishikawa M, Mizobuchi M, Takahashi H, Bando H, Saito S. Somatostatin release as measured by in vivo microdialysis: circadian variation and effect of prolonged food deprivation. Brain Res. 1997;749:226-31.

Izquierdo-Claros RM, MDC BLO-A, Arilla-Ferreiro E. Acutely administered melatonin decreases somatostatin-binding sites and the inhibitory effect of somatostatin on adenylyl cyclase activity in the rat hippocampus. J Pineal Res. 2004;36:87-94

Klein SE, Sheridan MA. Somatostatin signaling and the regulation of growth and metabolism in fish. Mol Cell Endocrinol. 2008;286:148-54.

Lee LT, Siu FK, Tam JK, Lau IT, Wong AO, Lin MC, Vaudry H, Chow BK. Discovery of growth hormone-releasing hormones and receptors in nonmammalian vertebrates. Proc Natl Acad Sci. 2007;104:2133-8.

Luque RM, Park S, Kineman RD. Role of endogenous somatostatin in regulating $\mathrm{GH}$ output under basal conditions and in response to metabolic extremes. Mol Cell Endocrinol. 2008;286:155-68.

Maitra SK, Chattoraj A, Mukherjee S, Moniruzzaman M. Melatonin: a potent candidate in the regulation of fish oocyte growth and maturation. Gen Comp Endocrinol. 2013;181:215-22.

McLean E, Devlin RH, Byatt JC, Clarke WC, Donaldson EM. Impact of a controlled release formulation of recombinant bovine growth hormone upon growth and seawater adaptation in coho (Oncorhynchus kisutch) and chinook (Oncorhynchus tshawytscha) salmon. Aquaculture. 1997;156:113-28.

Moore AF, Menaker M. The effect of light on melatonin secretion in the cultured pineal glands of Anolis lizards. Comp Biochem Physiol A Mol Integr Physiol. 2011;160:301-8.

Nikaido Y, Ueda S, Takemura A. Photic and circadian regulation of melatonin production in the Mozambique tilapia Oreochromis mossambicus. Comp Biochem Physiol A Mol Integr Physiol. 2009;152:77-82.

Norberg B, Weltzien FA, Karlsen $\varnothing$, Holm JC. Effects of photoperiod on sexual maturation and somatic growth in male Atlantic halibut (Hippoglossus hippoglossus L.). Comp Biochem Physiol B Biochem Mol Biol. 2001;129:357-65.

Oliveira C, Garcia EM, López-Olmeda JF, Sánchez-Vázquez FJ. Daily and circadian melatonin release in vitro by the pineal organ of two nocturnal teleost species: Senegal sole (Solea senegalensis) and tench (Tinca tinca). Comp Biochem Physiol A Mol Integr Physiol. 2009;153:297-302.

Peinado MA, Fajardo N, Hernandez G, Puig-Domingo M, Viader M, Reiter RJ Webb SM. Immunoreactive somatostatin diurnal rhythms in rat pineal, retina and harderian gland: effects of sex, season, continuous darkness and estrous cycle. J Neural Transm. 1990;81:63-72.

Qian Y, Yan A, Lin H, Li W. Molecular characterization of the GHRH/GHRH-R and its effect on $\mathrm{GH}$ synthesis and release in orange-spotted grouper (Epinephelus coioides). Comp Biochem Physiol B Biochem Mol Biol. 2012; 163:229-37.

Raven PA, Sakhrani D, Beckman B, Neregård L, Sundström LF, Björnsson BT, Devlin $\mathrm{RH}$. Growth and endocrine effects of recombinant bovine growth hormone treatment in non-transgenic and growth hormone transgenic coho salmon. Gen Comp Endocrinol. 2012;177:143-52.

Revel FG, Saboureau M, Masson-Pévet M, Pévet P, Mikkelsen JD, Simonneaux V. Kisspeptin mediates the photoperiodic control of reproduction in hamsters. Curr Biol. 2006;16:1730-5.

Sheridan MA, Hagemeister AL. Somatostatin and somatostatin receptors in fish growth. Gen Comp Endocrinol. 2010;167:360-5.

Takemura A, Susilo ES, Rahman MD, Morita M. Perception and possible utilization of moonlight intensity for reproductive activities in a lunarsynchronized spawner, the golden rabbitfish. J Exp Zoolog A Comp Exp Biol. 2004;301:844-51.

Taylor JF, Migaud H, Porter MJR, Bromage NR. Photoperiod influences growth rate and plasma insulin-like growth factor-l levels in juvenile rainbow trout, Oncorhynchus mykiss. Gen Comp Endocrinol. 2005;142:169-85.

Very NM, Knutson D, Kittilson JD, Sheridan MA. Somatostatin inhibits growth of rainbow trout. J Fish Biol. 2001;59:157-65.

Wan X, Zhang X, Huo Y, Wang G. Weather entrainment and multispectral diel activity rhythm of desert hamsters. Behav Process. 2013;99:62-6.

Wood AW, Duan C, Bern HA. Insulin-like growth factor signaling in fish. Int Rev Cytol. 2005;243:215-85.

Xing Y, Wensheng L, Haoran L. Polygenic expression of somatostatin in orangespotted grouper (Epinephelus coioides): molecular cloning and distribution of the mRNAs encoding three somatostatin precursors. Mol Cell Endocrinol. $2005 ; 241: 62-72$.

\section{Submit your next manuscript to BioMed Central and we will help you at every step:}

- We accept pre-submission inquiries

- Our selector tool helps you to find the most relevant journal

- We provide round the clock customer support

- Convenient online submission

- Thorough peer review

- Inclusion in PubMed and all major indexing services

- Maximum visibility for your research

Submit your manuscript at www.biomedcentral.com/submit
Biomed Central 